\title{
Derecho penal económico. Lineamientos de política penal ${ }^{*}$ Economic criminal law. Criminal policy guidelines
}

\author{
Juan María Terradillos Basoco**
}

\section{RESUMEN}

La globalización económica ha obligado a la politica criminal a asumir nuevos retos. En concreto, el derecho penal económico ha de redefinir, inicialmente, sus objetivos básicos: qué conductas desea prohibir y castigar. La siguiente cuestión a la que ha de enfrentarse es de naturaleza teleológica: la politica criminal racional es de orientación preventiva, por tanto ha de enmarcarse en un contexto de politicas sociales y económicas de idéntica orientación. Al derecho penal no le corresponde liderar ese proceso, pero tampoco puede inhibirse ante la criminalidad económica: última ratio no es nulla ratio. Ese derecho penal ha de ser construido a la vista de las caracteristicas especiales del marco económico -la globalización-y de los agentes económicos -las empresas-, y ha de responder a los principios garantistas de la politica criminal propia del Estado social de derecho.

PALABRAS CLAVE: Criminalidad económica, criminalización, delitos de cuello blanco, derecho penal de la empresa, descriminalización, Estado social de derecho, globalización económica, politica criminal, politica penal y procesal, principios democráticos.

\section{ABSTRACT}

Criminal policy has been forced by economic globalization to assume new challenges. Specifically, economic criminal law has to redefine in first place its basics objectives: what actions must been punished and banned. Next issue that should be faced is a teleological nature question: rational criminal policy is targeted to prevention, so it has to form part of a social and economic policy context based on the same aim. Criminal law is not the one to be the leader of this process, even though criminal law should refrain from economic criminality: ultima ratio doesn't mean nulla ratio. This criminal law has to be built taking into consideration the economic frame special features -globalization- and the economic agent ones -companies-, but it also has to meet the guarantee principles of the criminal policy from a social State based on the rule of law.

KEY WORDS: Criminal and procedural policy, criminal business law, criminalization-decriminalization, democratic principles, economic criminality, economic globalization, social State based on the rule of law, white collar crimes.

\footnotetext{
* Recibido: 29 de septiembre de 2014. Aceptado: 3 de noviembre de 2014.

** Catedrático de Derecho penal en la Universidad de Cádiz, España (juan.terradillos@uca.es).
} 


\section{Sumario}
1. Introducción
2. ¿Qué?
3. ¿Para qué?
4. ¿Quién?
5. ¿Dónde?
6. ¿Cómo?
A) Principio de lesividad
B) Delitos de peligro
c) Características de los sujetos intervinientes
D) Accesoriedad y remisión normativa
E) Directrices criminalizadoras
F) Cuestiones procesales
7. Epílogo

\section{Introducción ${ }^{1}$}

La globalización económica, más allá de los juicios valorativos a los que se haga acreedora, constituye una realidad de implantación amplia, que trasciende las fronteras nacionales. Y, en cuanto homogeneiza las condiciones en que se desarrolla la actividad mercantil, genera también formas comunes de delincuencia, susceptibles, a su vez, de respuestas institucionales internacionalmente aceptadas.

No debe desconocerse, sin embargo, que la globalización, asentada en los presupuestos ideológicos del neo-liberalismo, ha potenciado la desigualdad y que, en consecuencia, la homogenización de reglas no se ha traducido en una mayor igualdad en las condiciones de vida de los individuos o de los grupos, sino en la vigencia de la lex mercatoria como primera referencia normativa, por encima de derechos humanos fundamentales, de principios constitucionales retóricamente intangibles o de convenciones internacionales que obligan y limitan a los Estados firmantes. Las consecuencias son de sobra conocidas.

No parece discutible la afirmación de que, para fijar los cimientos de una política criminal eficiente frente a la delincuencia económica, es imprescindible ubicarse en el marco -económico- en el que esta nace y del que recibe las características definidoras de sus contenidos esenciales.

Si bien es cierto que los mercados han venido dibujando un paisaje global monocolor, también lo es la posibilidad de identificar zonas diferenciadas. La

1 El trabajo se enmarca en el Grupo de Investigación (Junta de Andalucia) PAI SEJ-378. Con las necesarias modificaciones, el texto se corresponde con la conferencia pronunciada en el vII Encuentro Internacional Justicia y Derecho, Tribunal Supremo Popular de Cuba, La Habana, 21 de mayo de 2014. 
aludida desigualdad, que deriva necesariamente de la entronización del "fundamentalismo del mercado" - por emplear la terminología del premio Nobel STIGLITZ-, es el factor causal desencadenante de situaciones distintas, dentro del modelo único. ${ }^{2}$ Por otra parte, la realidad no siempre se adecúa en su integridad a las pautas generales del modelo. La función social de la propiedad, por ejemplo, que ciertas constituciones políticas proclaman, debería introducir elementos de corrección, con incidencia distinta en cada país, según su realidad política se escore más hacia la vigencia o hacia la postergación de esa teórica función. Algún vestigio del pensamiento keynesiano es, a su vez, reconocible en ámbitos de implantación socialdemócrata, mientras que otros contextos, los mayoritarios, ya se decantaron fervorosamente del lado de las propuestas más genuinamente neo-liberales.

En síntesis, globalización tendencialmente monocorde, con enclaves matizadamente diferenciados. Cuba constituye uno de estos enclaves, acreedor de referencia específica tanto por el statu quo que representa como por la dinámica que impulsa.

Según se declara en el Preámbulo al Código Penal cubano de 1987, el derecho penal socialista "tiene que desarrollarse para servir con eficacia creciente a los fines de nuestra sociedad y, de conformidad con este principio, la política penal acordada por el Estado debe reflejar, en esencia, las formas de lucha contra el delito y la delincuencia, atendiendo a las condiciones sociales, políticas y económicas de nuestro país".

En el ámbito de esas condiciones económicas tiene especial incidencia, a los efectos que aquí interesan, la Ley No. 118, Ley de la Inversión Extranjera (Ley 118), aprobada el 29 de marzo de 2014, con una vacatio legis de noventa días. El objetivo explicitado en su artículo 1.1, es el de establecer el marco de la inversión extranjera "para contribuir a nuestro desarrollo económico en función de una sociedad socialista próspera y sostenible".

Meses más tarde, en diciembre de 2014 se han anunciado los primeros pasos, inicialmente solo simbólicos, dirigidos a la superación del bloqueo impuesto a Cuba por los Estados Unidos hace ya cincuenta y tres años. Si bien, hasta que el Congreso norteamericano derogue la ley Helms-Burton, el bloqueo va a seguir siendo una realidad, lo cierto es que algunos de sus aspectos pueden ser modulados por el presidente. Lo que permite intuir la presencia de ciertos elementos dinamizadores.

Con independencia de los posibles resultados futuros de ese proceso, la ya vigente Ley 118 , aunque no cambia el panorama jurídico-penal, tiene una in-

\footnotetext{
2 Terradillos Basoco, Juan Maria. "Cuatro décadas de política criminal en materia socioeconómica", en Demetrio Crespo, EduARDo (dir.). Crisis financiera y derecho penal económico, Edisofer-B de F, Madrid-Buenos Aires, 2014, p. 48.
} 
cidencia cierta en la dinámica económica, que no solo va a incorporar nuevos sujetos corporativos; también nuevas formas de actuación.

Esos sujetos económicos provienen del mercado (global) y, tendencialmente, se proyectan al mercado (global). Lo que comporta, como inevitable consecuencia, que Cuba, todo lo matizada o parcialmente que se quiera, está abocada a desafíos político-criminales comunes a la economía globalizada. Y, como la posibilidad de patología acompaña a todo lo humano, habría que sospechar que la actividad económica no es una excepción: allí donde puede impulsar procesos socialmente útiles, puede también dar cobijo a comportamientos irregulares 0 , incluso, delictivos.

Esos comportamientos delictivos, en el marco de una economía planificada, con fuerte protagonismo del sistema público, aparecen, de facto, vinculados a formas de corrupción, a pesar de que las evidentes concomitancias entre ambos grupos de delitos no pueden ocultar la diferencia básica que los separa: aquellos tienen contenido patrimonial y afectan a la dinámica económica, mientras que la corrupción se mueve en el ámbito de la función pública y afecta al funcionamiento de la Administración. ${ }^{3}$

Este importante elemento diferenciador no permite ignorar, sin embargo, la existencia de puentes que contactan, hasta lograr que, en ocasiones, se superpongan, corrupción pública y corrupción económica. $Y$ no solo en los sistemas de economía planificada. También en los modelos regidos por el mercado la corrupción entre particulares puede tener consecuencias que trascienden las fronteras de los intereses privados y que pueden adquirir dimensión institucional-colectiva. Un buen ejemplo lo brindan, en España, las prácticas corruptas que acabaron, entre 2008 y 2012, con el conglomerado de Cajas de Ahorro, entidades financieras a las que, materialmente, hubo que "rescatar" mediante aportes ingentes de dinero público: 22.424 millones de euros solo para una de ellas, Caja Madrid. ${ }^{4}$ No solamente fueron públicos los fondos del rescate, por cuanto el control de las Cajas estaba en manos de instituciones públicas, $y$, a través de ellas, de los partidos políticos con implantación en cada ámbito geográfico. ${ }^{5}$

Desde una perspectiva criminológica, en la que asentar científicamente el diseño de estrategias político-criminales, la corrupción en el sector público y

\footnotetext{
${ }^{3}$ Mejias Rodriguez, Carlos Alberto. "Ámbito procesal del derecho penal económico en Cuba", en Justicia y Derecho. Revista del Tribunal Supremo Popular de la República de Cuba, núm. 15, 2002, pp. 133 y 134.

${ }^{4}$ Véase http://www.elconfidencial.com/economia/2013/03/26/el-frob-da-por-perdidos-10000-millones-delrescate-de-bfabankia-117594/ [Consulta: 31.Enero.2015].

${ }^{5}$ Grupo de Estados contra la corrupción del Consejo de Europa (GRECo), Informe de la lucha contra la corrupción de la Unión Europea, Comisión Europea, Bruselas, 2014, p. 5. Disponible en: http://ec.europa.eu/dgs/home-affairs/ what-we-do/policies/organized-crime-and-human-trafficking/corruption/anti-corruption-report/docs/2014_acr_ spain_chapter_es.pdf [Consulta: 31.Enero.2015].
} 
la corrupción en el sector privado presentan, pues elementos comunes y zonas secantes. Pero también características diferenciales no desdeñables. La principal, y ya aludida, es que los objetivos del sector privado se limitan a la obtención de la máxima rentabilidad; mientras que en "lo público" - o en lo que queda de "lo público" desde los embates procedentes del modelo neoliberal- los objetivos se centran en la tutela de los derechos, intereses, principios e instituciones constitucionalmente impuestos.

La corrupción en el sector público comporta, pues, burla de los objetivos constitucionales - vinculantes en todos los niveles en que se ejerce el poder político, desde la elaboración de leyes a los actos administrativos singulares- que quedan traicionados en favor de los intereses particulares de los gestores del poder o de quienes irrumpen, desviándolo, en el proceso de toma de decisiones por parte de estos. Desde la perspectiva administrativa y jurídico-política, la corupción es, ante todo, desviación, por parte de autoridades y funcionarios, del interés público legalmente determinado. ${ }^{6}$

Pero lo habitual es que en el origen de la corrupción pública concurran incentivos privados: es el particular quien, con su poder económico, pretende torcer en su favor el funcionamiento de las instituciones. ${ }^{7}$ De ahí que en el combate contra la corrupción no puedan quedar preteridas las estrategias dirigidas al sector privado. Transparencia Internacional, la principal organización no gubernamental dedicada a la lucha contra la corrupción, por ejemplo, propone como "Principios de transparencia y prevención para las empresas", entre otros, los siguientes: información pública de las contrataciones con el sector público e información de las actividades subvencionadas con ayudas públicas, evitación de prácticas de corrupción de funcionarios extranjeros en las transacciones internacionales, o cumplimiento empresarial de las obligaciones fiscales. Se trata de principios dirigidos, en principio, a "contribuir a una competencia leal y en condiciones de igualdad entre los concurrentes”, pero también a reducir la incidencia de los intereses privados en la corrupción pública. ${ }^{8}$

Las dos modalidades de corrupción provocan una inevitable distorsión del mercado y un perjuicio cierto para competidores y consumidores; y ambas comparten una causa generadora común, de índole económica. ${ }^{9}$ Pero la pública

\footnotetext{
${ }_{6}$ Demetrio Crespo, Eduardo. "Consideraciones sobre la corrupción y los delitos contra la administración pública", en Ferré Olive, Juan Carlos (ed.). Fraude y corrupción en la administración pública. Delitos financieros, fraude y corrupción en Europa, Universidad de Salamanca, 2002, vol. 3, p. 176.

7 Muñoz Conde, Francisco. Derecho penal. Parte especial, 19a. ed., Tirant lo Blanch, Valencia, 2013, p. 928.

${ }^{8}$ Véase http://www.transparencia.org.es/PRINCIPIOS_TRANSPARENCIA_PARA_EMPRESAS/Principios_de_Transparencia_ Empresas\%20_Resumen_Ejecutivo.pdf [Citado: 31.Enero.2015].

9 Almoguera Carreres, Joaquin. "Corrupción y mercados internacionales", en Ruiz Miguel, Alfonso (ed.). Entre Estado y cosmópolis. Derecho y justicia en un mundo global, Trotta, Madrid, 2014, p. 325.
} 
añade elementos específicos que afectan al funcionamiento de las instituciones. Y esa es la perspectiva que adoptó, en los Estados Unidos, la estimada norma pionera, y sumamente influyente, en la materia, la Foreing Corrupt Practices Act de 1977.

La corrupción pública o política no está, pues, tan alejada de los ámbitos que tradicionalmente se asignan a la delincuencia socioeconómica, ya que, en sus manifestaciones reales, implica la concurrencia tanto del funcionario, autoridad o sujeto con poder de tomar, inducir o potenciar decisiones políticas, como del particular económicamente interesado en imprimir a estas un determinado sesgo.

Además se trata de decisiones que tienen un precio, satisfecho por el delincuente de cuello blanco, en el ámbito de su actividad profesional-empresarial, a la vista de los beneficios económicos que le puede reportar la ilegal operación. A su vez, esos beneficios tienen un alto coste, tanto como importantes sean las competencias del servidos público corrupto, y, por lo mismo, se espera lograr mediante su pago una rentabilidad no accesible a la delincuencia patrimonial tradicional y solo posible en el entorno de las grandes obras públicas, de la concesión de servicios - vitales en buena parte de casos para amplios sectores de población-, de privatizaciones con rentabilidad anunciada, etcétera. El envés de los exorbitantes beneficios de corruptos y corruptores, es la dañosidad de estas maniobras para con los derechos e intereses de mayorías significativas, damnificadas por la asignación aberrante de los recursos públicos y por la supeditación de los objetivos sociales legalmente pretendidos a otros, particulares, incompatibles con ellos.

En la corrupción política concurren pues, al menos en el plano criminológico, todos los elementos que caracterizan a la delincuencia socioeconómica, ${ }^{10}$ a los que se añade la perversión de las instituciones públicas y de sus responsables. Este dato es, criminológicamente, relevante: la Administración se implica en el proceso delictivo a instancias y en interés de las pretensiones económicas particulares; lo que, en una perspectiva político-criminal, comporta que las estrategias preventivas solo pueden ser mínimamente eficaces si se dirigen tanto a la depuración de las instituciones públicas como a la neutralización de los factores criminógenos aportados por la realidad económica.

Las peculiaridades de las relaciones entre corrupción pública y corrupción económico-privada van a venir determinadas, en lo fundamental, por el peso que en el modelo económico tengan, respectivamente, lo público y lo privado.

\footnotetext{
10 Fernández Garcia, Julo. "Algunas reflexiones sobre la corrupción política", en Fabián Caparrós, E. y Pérez Cépeda, Ana (coords.). Estudios sobre corrupción, Ratio Legis, Salamanca, 2010, p. 46.
} 
De ahí que, en la economía planificada, la presencia progresivamente creciente de sujetos económicos privados puede dar lugar a modalidades de criminalidad distintas y no siempre previstas por un sistema jurídico-positivo diseñado para afrontar una realidad diferente.

La oportunidad de la reflexión sobre los denominados delitos socioeconómicos o, más sencillamente, económicos - contrapuestos a los tradicionales delitos patrimoniales- no puede, pues, ser cuestionada.

Viene incluso reforzada, para casos como el de Cuba, por otros fenómenos, como pueden ser "el auge que ha ido tomando la criminalidad económica y otras conductas que reflejan fenómenos vinculados a la corrupción en el contexto social cubano"; "11 el incremento de las actividades privadas o de índole particular junto a la presencia de la economía informal o subterránea -con la consiguiente implementación de mecanismos públicos de control y sanción-; el fortalecimiento del sistema tributario; el incremento de las inversiones foráneas -impulsadas previsiblemente por la citada Ley 118-; y, por último, los procesos de integración económica entre países latinoamericanos - por ejemplo, la Alternativa Bolivariana para los pueblos de América (ALBA) o la Comunidad de Estados del Caribe (САRICOM) - que inevitablemente exigen igualdad en las reglas del juego económico, y, por tanto, integración jurídico-penal. ${ }^{12}$

El nuevo marco está presente, con mayor o menor intensidad, por doquier. Lo que hace evidente no ya solo el interés, sino la necesidad de contar con un sistema normativo idóneo para dar respuestas nuevas y eficaces a fenómenos delictivos también nuevos y, por su lesividad, no baladíes.

La reflexión sobre ese nuevo orden normativo debe ir guiada a responder a las cuestiones fundamentales que se plantean ante toda iniciativa político-criminal que pretende rehuir la digresión bizantina y asentarse en la racionalidad. Las iniciales preguntas son ¿qué?, ¿para qué?, ¿quién?, ¿dónde? y ¿cómo?

\section{2. ¿Qué?}

La referencia a los delitos económicos, socioeconómicos o, por emplear la terminología del Código Penal español, delitos "contra el orden socioeconómico", remite a una de las más importantes e innovadoras apuestas de la moderna

\footnotetext{
"Mejias Rodriguez, Carlos Alberto. "Estrategias, necesidades y urgencias del derecho penal económico en Cuba", en Âmbito Juridico, Rio Grande, xv, 2012 (100). Disponible en: http://www.ambito-juridico.com.br/site/index.php/?n_ link=revista_artigos_leitura\&tartigo_id=11559\&trevista_caderno=3 [Consulta: 1 .Febrero.2015].

12 Terradillos Basoco, Juan Maria. "Derecho penal del trabajo: un reto para la integración penal supranacional", en Revista Brasileira de Ciências Criminais, Sâo Paulo, núm. 92, 2011, pp. 261-297.
} 
política criminal -la alemana Erste Gesetz zur Bekämpfung der Wirtschaftskriminalität (Primera ley para la lucha contra la Criminalidad Económica) data de 1976, y la Foreign Corrupt Practices Act, Estados Unidos, de 1977-, decidida a ampliar la intervención penal, restringida con anterioridad a los tradicionales delitos patrimoniales.

Aunque doctrinalmente se han ensayado, y rebatido, múltiples criterios para delimitar los ámbitos respectivos de la delincuencia económica y la patrimonial, son identificables ciertas zonas de consenso teórico.

Las primeras, en el plano criminológico: frente a los tradicionales delitos patrimoniales ya descritos en los códigos penales del siglo xIX y coherentes con un sistema económico bien diferente al del siglo xxı, los delitos económicos comportan una alta lesividad -no siempre presente en la vieja delincuencia patrimonial-, y son protagonizados por sujetos de cierta cualificación y status -son white collar crimes-, que utilizan estructuras e instrumentos comunes a la actividad económica lícita. En síntesis, como los definiría el primer sistematizador de la categoría, SutherLAnd, son delitos "cometidos por una persona de respetabilidad y status social alto en el curso de su ocupación".13

Se trata de una delincuencia vinculada a las estructuras de la globalización y financiarización de la economía, que genera ingentes costes económicos, entre los que deben contarse, junto a los perjuicios directos, los derivados de los efectos resaca y espiral. Además de la posibilidad de corrupción del funcionariado público -tal es el caso del notariado-, ${ }^{14}$ que normalmente acompaña a este tipo de criminalidad,$^{15}$ en la medida en que buena parte de los delitos de cuello blanco han de ir acompañados de falsedades documentales instrumentales. Por no aludir a las consecuencias devastadoras de los ajustes económicos de crisis financieras que, provocadas incluso delictivamente por unos pocos, terminan afectando de manera directa a las capas sociales más vulnerables, ${ }^{16} \mathrm{e}$ indirectamente, vía impuestos, a todos. ${ }^{17}$

Así, un criterio decisivo de identificación y diferenciación de los delitos socioeconómicos se encuentra en la desmesura de su dañosidad: al contrario que la

${ }_{13}$ Sutherland, Edwin H. El delito de cuello blanco, Universidad Central de Venezuela, Caracas, 1969, p. 13.

14 Mejias Rodriguez, Carlos Alberto. "Falsedad y falsificación en documentos notariales. Excursus sobre la responsabilidad penal del notario", en Archivos de Criminología, Criminalistica y Seguridad Privada, núm. Iv, 2010. Disponible en: www.somecrimnl.es.tl [Consulta: 1.Enero.2015].

${ }^{15}$ Terradillos Basoco, Juan Maria. Derecho penal de la empresa, Trotta, Madrid, 1995, p. 31.

${ }^{16}$ Berzosa Alonso-Martinez, Carlos. "Los efectos negativos de la globalización y propuestas alternativas", en Barañano Cid, MARGarita (dir.). La globalización económica. Incidencia en las relaciones sociales y económicas, Consejo General del Poder Judicial, Madrid, núm. 5, 2002, p. 136.

17 Terradillos Basoco, Juan Maria. "Derecho penal, sistema económico y empresa", en Falconi, Ramiro et al. Derecho penal económico, Rubinzal, Buenos Aires, 2012, p. 122. 
criminalidad patrimonial, los delitos contra el orden socioeconómico apuntan a bienes jurídicos inmateriales, institucionalizados o espiritualizados, de titularidad social o colectiva. ${ }^{18}$

Este conjunto de bienes jurídicos no debe ser identificado con la intervención del Estado en la economía, como sugiere el concepto de derecho penal económico que la doctrina española viene denominando "estricto" y al que parece apuntar el artículo 1.1 del Código Penal cubano cuando proclama, como objetivo propio, la protección del “orden social, económico y político". El derecho penal es instrumento sumamente tosco como para brindar protección integral al orden económico. Carece de elementos promocionales capaces de impulsar, en positivo, la dinámica del mercado. El derecho penal, lejos de palanca para el avance es instrumento de resistencia: se limita a intentar tutelar preventivamente los bienes jurídicos que están en la base, y en la meta, de la política económica. No la política económica en sí, sino los bienes jurídicos relevantes que ésta necesita o que es capaz de generar.

Es cierto que, como advierte Mejías, el sistema jurídico, en un Estado de derecho, se orienta hacia "la protección del rol del Estado en el orientación y dirección de la política económica o mejor aún el orden económico estatal, así como [hacia] la protección de bienes jurídicos supraindividuales y colectivos de carácter patrimonial". ${ }^{19}$ Pero no todo el ordenamiento jurídico asume indiferenciadamente los mismos objetivos: el orden económico estatal viene tutelado, en general, por mecanismos extrapenales; los bienes jurídicos colectivos de contenido económico, cuando son objeto de ataques intolerables, son protegidos por el derecho penal económico.

Así, el orden socioeconómico constituye el marco en el que se entrecruzan un amplio conjunto de intereses, principios y valores. La afectación relevante a esos elementos esenciales del sistema, en cuanto constituidos en bienes jurídicos, brinda la base inicialmente legitimadora de la punición de los delitos socioeconómicos. La lesividad -siquiera sea solo potencial-para lo colectivo se erige, así, en un criterio diferencial básico con respecto a los delitos patrimoniales.

Dentro ya del ámbito de la delincuencia económica, desde la criminología se pueden establecer subcategorías -la clasificación más utilizada diferencia entre criminalidad económica en la empresa y criminalidad económica de la empresa-, pero, a los efectos que aquí interesan, esas distinciones tienen utilidad solo relativa. Los delitos contra la empresa o contra alguno de sus elementos, cuando son protagonizados por la propia cúspide empresarial pasan a ser delitos de

\footnotetext{
18 Terradillos Basoco, Juan María. "Delitos contra el orden socioeconómico", en Terradillos Basoco, Juan Maria (coord.). Derecho penal. Parte especial (derecho penal económico), lustel, Madrid, 2012, pp. 17 y 18.

19 Mejias Rodriguez, Carlos Alberto. "Estrategias, necesidades y urgencias del derecho penal económico en Cuba", cit.
} 
la empresa. Y en otros casos, como la divulgación de secretos industriales o la administración fraudulenta, se trata de delitos que están a caballo entre los patrimoniales y los económicos, dependiendo la adscripción a una u otra categoría de su dimensión cuantitativa.

Lo relevante es estudiar conjuntamente lo que, como fenómeno, aparece conjuntamente..$^{20} \mathrm{Y}$, cara a ese objetivo, el derecho positivo no puede constituir la referencia única. En efecto, lo procedente es partir, críticamente, de sus limitaciones, para proponer nuevas opciones criminalizadoras/descriminalizadoras. Lo que exige tener en cuenta las indicaciones suministradas por la criminología, necesarias para identificar las conductas que, criminalizadas o no por el derecho positivo, ameriten serlo, precisamente bajo el rubro de delitos económicos. ${ }^{21}$

\section{3. ¿Para qué?}

La respuesta a este interrogante es común a todo el sistema penal: su función racional es la tutela de bienes jurídicos, a través de la prevención de delitos.

El objetivo es, pues, según se ha advertido, la protección de bienes jurídicos y no de funciones (sic et simpliciter, de políticas económicas públicas). Del mismo modo que cuando, en el Código penal cubano se castigan los delitos de lesiones (artículos 272 y siguientes), no se protegen penalmente las políticas públicas en materia de sanidad, o que cuando se castigan delitos contra los derechos de los trabajadores (artículo 296), no se protegen las políticas públicas de prevención de riesgos laborales, cuando se castigan los delitos socioeconómicos no se debería estar protegiendo las políticas económicas públicas, sino los bienes jurídicos identificados en su seno.

Con independencia -es obvio- de que la represión penal no pueda buscar fines contrapuestos a los propios de esas políticas.

En efecto, el derecho penal, si quiere ser eficaz -y legítimo- ha de integrarse en la panoplia de medios propios de una política social, no ya solo criminal, de amplio espectro dirigida a la tutela de los derechos, intereses o principios propios del modelo económico: pero, en ese contexto, mientras a otras ramas del derecho les competen funciones de promoción, control o, incluso, sanción, al derecho penal solo se le puede confiar la tutela de bienes jurídicos relevantes (principio de lesividad) frente a los ataques más insoportables (principio de frag-

20 Terradillos Basoco, Juan Maria. "Concepto y método del derecho penal económico", en Terradillos Basoco, Juan Maria. Estudios sobre derecho penal de la empresa, Editores del Puerto, Buenos Aires, 2009, p. 33.

21 Sarcedo, Leandro. Política criminal e crimes econômicos. Uma crítica constitucional, Alameda, São Paulo, 2012, pp. 103-110. 
mentariedad), ante los que esas otras ramas del ordenamiento han mostrado su impotencia (principio de subsidiariedad).

Por presión del principio de lesividad, procede, en el ámbito de la delincuencia socioeconómica, identificar tres categorias de bienes jurídicos supraindividuales: institucionalizados de titularidad individual o individualizable (por ejemplo, capacidad recaudatoria o recursos de la Hacienda pública), supraindividuales que constituyen elementos básicos del sistema (por ejemplo, patrimonio cultural) y colectivos o sociales funcionalmente necesarios para la defensa de otros individuales (por ejemplo, transparencia en el mercado bursátil para evitar perjuicios a los inversores). Esta clasificación despliega su eficacia práctica, ante todo, a la hora de seleccionar la técnica tipificadora, que ha de decantarse por el recurso a delitos de lesión o de peligro, según las características de cada caso (vide infra 6.в).

La tutela de estos bienes jurídicos constituye el reto principal del derecho penal económico, que no puede proponer una expansión ilimitada del ius puniendi, ni reivindicar una subversión de los principios de imputación penal. Mucho menos la transformación de la ley penal en herramienta emancipadora o superadora de desigualdades sociales con causas estructurales. El derecho penal, que actúa a través de la pena, no puede afrontar tan transcendentes objetivos y debe limitarse, primero, a considerar, con rigurosa observancia del principio de lesividad, en qué casos la actividad económica puede comportar ataques intolerables a bienes jurídicos relevantes, $\mathrm{y}$, en segundo lugar, a implementar respuestas coherentes con las características específicas de la realidad a la que se pretende hacer frente, pues su desconocimiento o preterición son prenda de ineficacia preventiva. ${ }^{22}$

\section{4. ¿Quién?}

Una vez identificados los objetivos, procede determinar a qué orden normativo compete la tutela de los bienes jurídicos implicados en el juego económico.

Pero ya se ha adelantado que ese objetivo es propio de todo el sistema social: como en tantos ámbitos delictivos, la prevención arranca con la educación cívica, ${ }^{23}$ a la que se añaden los instrumentos jurídico-privados, que incorporan elementos resarcitorios e indemnizatorios dotados en ocasiones de naturaleza

\footnotetext{
22 Terradillos Basoco, Juan Maria. "Delitos contra el orden socioeconómico", cit., p. 22.

23 Del Moral Garcia, Antonio. "La lucha contra la corrupción, una tarea jurídica, ética y educativa. Propuestas y perspectivas de la sociedad en la lucha contra la corrupción". Disponible en: http://www.instituto-social-leonxiii. org/index.php/cursos-dsi/121-curso-2013/952-la-lucha-contra-la-corrupcion?format=pdf [Citado: 1.Enero.2015].
} 
sancionadora - por ejemplo, cláusula penal de los contratos civiles-, los instrumentos jurídico-administrativos de incentivación, dirección, control y sanción y, finalmente, con carácter subsidiario además, los instrumentos jurídico-penales, de objetivos preventivos pero de contenidos sancionadores.

La incorporación a las leyes penales de los delitos económicos supuso una respuesta coherente a las exigencias del modelo de economía de mercado. En efecto, si a mediados del siglo pasado se generalizó la opinión, hija de la crisis económica de 1929, de que la reconstrucción requería suprimir el riesgo en las inversiones para evitar una situación abocada al $\mathrm{crack}_{b}$ lo coherente era atribuir al Estado la función de garante de las convenciones económicas fundamentales, en un intento de superar el riesgo en las inversiones. El Estado, por su parte, al asumir nuevas responsabilidades, necesitó recurrir a nuevos instrumentos, incluidos los jurídico-penales. ${ }^{24}$

Este movimiento expansivo no comporta necesariamente desmedro del principio de ultima ratio. Ultima ratio no es nulla ratio, y los límites constitucionales al ius puniendi han de convivir con la obligación estatal -que también goza de rango constitucional- de hacer frente a las necesidades preventivas.

Sin embargo, hoy, quizá porque se han mistificado ciertos elementos nucleares de ese modelo, se discute la utilidad e incluso la legitimación de la intervención del derecho penal en la actividad económica, incluso cuando lo hace, como no puede ser de otro modo, frente a las manifestaciones más patológicas de la misma. ${ }^{25}$

Se cuestiona, así, la criminalización del delincuente de cuello blanco, paradigmáticamente representado por el empresario, apelando a la consideración, banal, de que criminalizar a quien aparece, además de como infractor, como creador de riqueza, no tendrá más efecto que el de cegar las fuentes del progreso social.

En Cuba, por ejemplo, La Ley 118 acepta en su Preámbulo, que la inversión extranjera podrá contribuir al desarrollo sostenible de la economía cubana, al permitir "acceder a financiamiento externo, [y a] tecnologías y nuevos mercados, así como insertar productos y servicios cubanos en cadenas internacionales de valor y generar otros efectos positivos". Para ello, resulta imprescindible ofrecer al inversor foráneo garantías jurídicas que le aseguren la rentabilidad. En ese contexto, resulta omnipresente la tentación de mirar hacia otro lado, para evitar

\footnotetext{
${ }_{24}$ Terradillos Basoco, Juan Maria. "El derecho penal económico español: de la pujanza económica a la depresión", en Velásouez, Fernando et al. (coords.). Derecho penal y crítica al poder punitivo del Estado. Libro homenaje al profesor Nodier Agudelo Betancur I, Grupo Editorial Ibáñez, Bogotá, 2013, pp. 304 y 305.

25 Terradillos Basoco, Juan María. "Delitos contra el orden socioeconómico", cit., p. 20.
} 
responder a las infracciones cuando provienen de la "gallina de los huevos de oro", cuya presencia debe ser incondicionalmente asegurada.

Y cuando resulta imposible desconocer las irregularidades en que incurre el emprendedor, presunto creador de riqueza, se propone sucumbir a la "fascinación administrativista”, en cuya virtud la sanción administrativa, directa, contundente, especializada, se nos presenta como preferible a la lenta, formalizada e irreal intervención jurisdiccional. Olvidando que las sanciones administrativas, incluso las más contundentes, no son nada cuando se las compara con los beneficios ilegalmente obtenidos o cuando la empresa sancionada puede repercutirlas sobre los precios que pagan los consumidores. Su eficacia preventiva no puede ser alta, y más en un contexto -el de las corporaciones transnacionales- en que las multas realmente satisfechas se alejan muy mucho de las impuestas.

Es también recurrente el argumento de que la empresa constituye un marco instrumental de actividad económica del que conviene mantener alejado al derecho penal. Este debería perseguir, sí, los delitos cuando cometidos en el marco empresarial, pero limitándose a los casos de delincuencia común, no necesitados, por tanto, de estrategias propias. A partir de este parti pris, se cuestiona el acierto de recurrir al derecho penal para poner coto a un fenómeno de la complejidad, dinamicidad y anclaje estructural que caracterizan a la criminalidad económica. Pretender afrontarlos mediante delitos y penas, se asegura, sería tanto como incurrir en una inadmisible huida al derecho penal, condenada al fracaso. ${ }^{26}$

Hoy, estos planteamientos, que llevan a la inhibición penal en la materia, deben considerarse definitivamente enterrados.

No es posible, en efecto, con los datos en la mano seguir desconociendo la presencia y entidad de la gran delincuencia económica, frecuentemente transnacional y organizada conforme a parámetros propios de la empresa. De ahí la necesidad de que en el diseño de las líneas estratégicas de la política criminal, sea imprescindible tenerla en cuenta. Conclusión a la que, por otra parte, obligan las declaraciones constitucionales que, incluso en marcos de economía de mercado, subrayan la función social de la propiedad y la primacía de valores superiores e intereses generales por encima de las exigencias meramente mercantiles.

No se trata de dar cobertura a una indiscriminada criminalización de las conductas empresariales irregulares, que no solo resultaría ilegítima sino también disfuncional. Pero tampoco cabe la inhibición cuando esas conductas afecten a bienes jurídicos esenciales. Entre el exceso "punitivista” y la abstención, entre huir al derecho penal y huir del derecho penal, opciones ambas incompatibles

${ }_{26}$ Terradillos Basoco, Juan Maria. "Concepto y método del derecho penal económico", cit., p. 30. 
con estrategias preventivas funcionales, es preciso encontrar el equilibrio político y la corrección técnica.

Si hoy se llevan estas propuestas al derecho penal cubano en la materia, se observa cierta obsolescencia, al menos si se le pone en relación con un fenómeno tan nuevo, complejo y dinámico como es la delincuencia económica. Es cierto que el modelo no se hace acreedor de la crítica de expansionismo punitivo, pero tampoco "gratifica las exigencias del derecho penal económico como en la actualidad se plantea”. ${ }^{27}$

\section{5. ¿Dónde?}

Las estrategias preventivas no pueden ser diseñadas prescindiendo de las características del medio en el que se pretende sean implementadas. Y el medio en el que nace y se desarrolla la actual criminalidad económica es la globalización, que comporta superación de fronteras por parte de la actividad económica y, en consecuencia, por parte de la actividad económica delictiva.

La globalización, en efecto, ha abierto cauces para que formas tradicionales de delincuencia alcancen una dimensión hasta ahora desconocida, multiplicando exponencialmente no sólo la rentabilidad del delito, sino también las posibilidades de actuación organizada supranacional, con la consiguiente capacidad para eludir la acción de la justicia.

La desregulación -característica esencial de la globalización en los ámbitos que quedan confiados al mercado - abre además amplísimos espacios al tratamiento diferenciado de ciertas conductas que, ilícitas o delictivas en ciertos entornos, son atípicas en otros. De ahí la importancia de fenómenos como la segmentación del proceso productivo en unidades jurídicamente autónomas o la -frecuentemente simultánea- deslocalización, que permiten a las empresas una mejor selección de ámbitos -cronológicos, geográficos, culturales, normativos- en los que ubicarse, ya que pueden trasladarse de un país a otro en busca de la máxima rentabilidad, condicionada, entre otros factores, por la disciplina fiscal, laboral, ambiental, etcétera, a que se ve sometida su actividad. La descriminalización de comportamientos contaminantes, antisindicales o de explotación - fruto de la búsqueda a ultranza de la reducción de costes- condiciona el flujo de inversiones. Y, a la inversa, la necesidad de inversiones de origen foráneo condiciona las opciones político-criminales.

27 Mejias Rodriguez, Carlos Alberto. "Estrategias, necesidades y urgencias del derecho penal económico en Cuba", cit. 
En ese contexto, el derecho penal se "jibariza" y queda reducido a instrumento ancilar de la política económica, olvidando su vocación de tutela de bienes jurídicos y se limita, en el mejor de los casos, a una inocua función simbólica.

Por otra parte, el marco natural de la actividad socioeconómica es la empresa, cuyas características propias constituyen un caldo de cultivo de fenómenos criminales específicos.

La organización empresarial, stricto sensu, responde a los principios de división del trabajo, especialización y complementariedad, que fijan límites a la competencia funcional de cada sujeto, cuyas aportaciones laborales interaccionan con otras, pero dentro de un plan único. A su vez, la descentralización y la delegación de funciones obligan a plantearse la posible responsabilidad de los cargos intermedios y la co-responsabilidad de los directivos. Además, como se tipifican comportamientos de sujetos que intervienen en el tráfico económico desde posiciones fuertemente formalizadas que comportan deberes específicos, es frecuente la configuración de estos delitos como especiales.

De este modo, lo específico empresarial se proyecta sobre diferentes ámbitos de relevante interés político-criminal y dogmático: $a$ ) delimitación de los bienes jurídicos afectados respetando las exigencias impuestas por los principios de lesividad y legalidad; $b$ ) pluralidad cuantitativa y cualitativa de fuentes reguladoras, lo que obliga a estudiar especialmente las técnicas a través de las que la ley penal se integra con otros niveles normativos; $c$ ) desde la perspectiva de la pluralidad y heterogeneidad de sujetos, la estructura empresarial presenta también zonas dignas de análisis especifico, tales como la responsabilidad de los directivos, las fuentes de la posición de garante dentro de la empresa, o el alcance de los deberes de vigilancia, con detenimiento en la aplicabilidad a este ámbito de la teoría del dominio del hecho por control de un aparato organizado de poder, con la conocida y polémica consecuencia de estimar autor (mediato) al "hombre de atrás" y autor "inmediato" al instrumento doloso; $d$ ) a estas cuestiones se superponen las suscitadas por el hecho de que, normalmente, la empresa es realidad económica que reviste la forma jurídica de sociedad mercantil, lo que obliga a regular la responsabilidad penal de las personas jurídicas; e) la afectación a bienes jurídicos colectivos comporta afrontar la dogmática de los delitos de peligro; f) la posible incidencia conjunta en bienes jurídicos colectivos e individuales suscita complejas cuestiones concursales, etcétera. ${ }^{28}$

El protagonismo de las grandes corporaciones en la economía globalizada obliga también a plantearse la problemática propia de los grupos de empresas, es decir de la concurrencia de varios empresarios, generalmente sociedades,

28 Terradillos Basoco, Juan Maria. "Delitos contra el orden socioeconómico", cit., p. 25. 
para integrar, bajo una dirección única, una unidad económica, pero sin perder ninguna de ellas su autonomía jurídica. Aquí el sujeto decisor -la sociedad matriz- está tan alejado, material y jurídicamente, de los instrumentos ejecutivos, que la posibilidad misma de identificación de un centro de imputación, objetiva y subjetiva, se complica en extremo, y más aún cuando las empresas agrupadas tienen diferente nacionalidad, con lo que el grupo -la multinacional- actúa, incluso delictivamente, en varios países, pero, sin personalidad jurídica unitaria; o cuando las empresas, individualmente consideradas, operan por encima de las fronteras estatales, con elementos instrumentales y personales que ostentan nacionalidades distintas. En estos casos, la disparidad de regulaciones puede favorecer la elusión de responsabilidad de cada una de las empresas, ${ }^{29}$ lo que lleva a pensar que la búsqueda de impunidad es una de las razones que da sentido a su agrupación.

\section{6. ¿Cómo?}

Las estrategias para afrontar la gran delincuencia de cuello blanco han de responder, en primer lugar, al respeto a los principios y garantías propias del derecho penal democrático, "que deben ser inviolables" ${ }^{30}$

No es necesario, en el plano dogmático, y no es admisible, en el político, provocar en la materia una ilimitada expansión punitiva o una reformulación a la baja de garantías y principios de imputación. Las diferencias entre el derecho penal económico y derecho penal "clásico" han de radicar, así, "en la modalidad operativa utilizada para delinquir y no en mecanismos excepcionales de imputación". ${ }^{31}$ Obsérvese que, incluso en la exigencia de responsabilidad penal a las personas jurídicas, doctrina y jurisprudencia se esfuerzan por aplicar, siquiera sea analógicamente, los mismos criterios de imputación que en el caso de las personas físicas. No es necesario, por tanto, asumir la gestación de una nueva disciplina académica, con contenidos y metodología propios, lo que no quita fuerza a la reivindicación de una mayor presencia, en las aulas universitarias, de estudios de derecho penal económico. ${ }^{32}$

\footnotetext{
29 Ibidem, pp. 25 y 26.

30 Mejias Rodriguez, Carlos Alberto. "Estrategias, necesidades y urgencias del derecho penal económico en Cuba", cit.

31 Cervini, Raúl y Adriasola, Gabriel. El derecho penal de la empresa, desde una visión garantista, B de F, MontevideoBuenos Aires, 2005, p. 135.

32 Carlos Alberto Mejias Rodriguez ("Ámbito procesal del derecho penal económico en Cuba", cit., pp. 116 y 117) prefiere subrayar la autonomía, aunque más que en el plano penal sustantivo, en el procesal, en el que identifica un conjunto de "principios propios" en el "compendio de resoluciones e indicaciones para los delitos económicos o asociados a la corrupción, elaborado y distribuido por la Fiscalia General de la República en 2009, y que recoge
} 
En segundo lugar, y dentro de ese marco, las estrategias político-criminales frente a la gran delincuencia económica han de diseñarse a la vista de las peculiaridades propias del mundo económico. De otro modo, quedarían reducidas a una sucesión de palos de ciego.

\section{A) Principio de lesividad}

El respeto al principio de lesividad sigue siendo un elemento nuclear de identificación de los sistemas penales democráticos. Y, precisamente, las mayores resistencias a la progresiva penetración del derecho penal en el mundo de la actividad económica, parten de la dificultad de identificación en ese ámbito de auténticos bienes jurídicos. Porque se difunde la idea, o la falacia, de que la delincuencia económica es creación artificial del legislador en refuerzo de intereses o funciones que nunca deberían ser considerados como bienes jurídicos. En definitiva, mala quia prohibita, meras desobediencias, no acreedoras de las graves consecuencias propias de la delincuencia tradicional.

Es cierto que, a pesar de la deriva desreguladora que impone el proceso globalizador, la actividad económica sigue discurriendo -y no contradictoriamente- entre líneas generales que fijan los poderes públicos. La política fiscal, las de gasto público, el control público de actividades que inciden en el medioambiente, en la salud de los consumidores, o en la competencia, son objeto de regulación, incluso minuciosa, con lo que siempre estará presente la tentación de, a espaldas del principio de lesividad, recurrir al derecho penal como mero refuerzo de disposiciones administrativas de control o promoción, o como instrumento de intervención dirigido a la tutela de mecanismos y funciones económicas.

Se trata de la tentación, denunciada paradigmáticamente por HASSEMER, de tomar el principio de lesividad o del bien jurídico no como límite de la criminalización, sino como su palanca impulsora, "convirtiendo dolorosamente la prohibición de exceso en una prohibición de defecto" ${ }^{33}$

Pero, en los hechos, no se puede constatar que, en esta materia, el legislador haya dejado de lado el principio del bien jurídico, como principio limitador del

un grupo de regulaciones dictadas por el Ministerio del Interior, la Fiscalia General de la República, la Contraloría General de la República, el Ministerio de Finanzas y Precios y el Tribunal Supremo Popular, vienen a darle en materia legislativa instrumental un carácter independiente dentro del derecho procesal penal". Quizá son más detectables notas de especificidad -aceptando un tronco común al que se añaden especialidades-que de independencia -que supone un modelo distinto-.

33 HaSSemer, Winfried y Muñoz Conde, Francisco. La responsabilidad por el producto en derecho penal, Tirant lo Blanch, Valencia, 1995, pp. 22 y 23. 
ius puniendi, para tomarlo como exigencia de penalización. Los bienes jurídicos puestos en juego por la delincuencia económica distan mucho de ser creaciones artificiales del legislador. Y, por otra parte, no parece que sea este ámbito el más acuciantemente necesitado de un recorte de la intervención punitiva. La nota clasista, que ha venido caracterizando al derecho penal como instrumento de control, no puede ser ignorada al reivindicar que se abstenga de ampliar su campo de acción a nuevas conductas, de gran lesividad, y que se mantenga en sus tradicionales ghettos de criminalidad de bagatela y de marginalidad.

Vida y salud de los trabajadores, vida y salud de los consumidores, derecho al medio ambiente, derecho al patrimonio histórico, artístico y cultural, etcétera, son bienes jurídicos de presencia añeja en nuestros ordenamientos. Como lo son los afectados por los delitos contra la propiedad industrial, contra derechos de los socios o contra la Hacienda Pública. Cuando asume su tutela penal, el legislador no está expandiendo artificialmente el ámbito de lo punible; está, simplemente, intentando articular medios de defensa frente a modalidades novedosas o sofisticadas de ataque.

\section{в) Delitos de peligro}

Precisamente, las peculiaridades de los bienes jurídicos "socioeconómicos" imponen el recurso a tipos de peligro. Que, a pesar de concitar recurrentes críticas, no tienen por qué comportar un debilitamiento de los criterios de imputación ni un desarme garantístico.

En efecto, no se trata de proponer un derecho penal de "segunda velocidad" para volver al peligro presunto. ${ }^{34}$ Aceptar esta presunción sería, simplemente, inconstitucional. Por el contrario, se pueden reivindicar los tipos de peligro cuando se piensa que peligro es probabilidad de un mal. Un mal que, en derecho penal, ha de ser afectación tangible a un bien jurídico. Lo que lleva a negar la admisibilidad de esos delitos de desobediencia o de no colaboración con el control administrativo, a los que la doctrina ha venido asignando, ante la ausencia de bien jurídico susceptible de lesión, la etiqueta de peligro para ocultar que no peligra nada (penalmente relevante).

Además, el peligro como probabilidad, exige una prueba de afectación negativa a la seguridad de un bien jurídico en el caso que se está juzgando: no

\footnotetext{
34 Terradillos Basoco, Juan Maria. "Sistema penal y empresa", en Terradillos Basoco, Juan Maria y Acale Sánchez, Maria (coord.). Nuevas tendencias en derecho penal económico. Seminario internacional de derecho penal, Universidad de Cádiz, Cádiz, 2008, p. 27.
} 
hay delito de peligro cuando se constata la probabilidad estadística, pero no la idoneidad lesiva del hecho concreto.

No hay tachas garantistas que oponer a la criminalización del peligro concebida en tan estrictos términos. Con todo, son las características del bien jurídico protegido en cada caso, y las modalidades típicas de afectación al mismo, las que deben aconsejar la opción a favor de tipos de peligro o de lesión.

Así, la tutela de bienes jurídicos institucionales de titularidad individual se puede articular mediante tipos de lesión. Es el caso, por ejemplo, de los delitos contra la Hacienda Pública, en los que lo colectivo pasa a un segundo plano porque, en los concretos tipos, un sujeto, la Administración, interviene constituyéndose en titular directo del bien jurídico afectado.

Más compleja resulta la protección penal de aquellos bienes jurídicos, colectivos, que, como el medio ambiente o el patrimonio cultural, se identifican con elementos estructurales del sistema, cuestión sobre la que es predominante la opinión de que es inevitable el recurso a delitos de peligro. Desde el punto de vista técnico, las posibilidades de recurrir funcionalmente a tipos de resultado lesivo son consideradas escasas por la doctrina: cuando se trata de bienes colectivos o sociales, normalmente afectados por procesos largos en el tiempo, en los que concurren multitud de elementos interrelacionados recíprocamente que provocan consecuencias que exceden la simple suma de las hipotéticamente generadas por cada uno de ellos - de modo que aquéllas, con ser vaticinables, no pueden ser apriorísticamente valoradas-, esperar a la constatación de lesión, y pretender que los contornos del resultado lesivo sean abarcados por el dolo del sujeto, es tanto como garantizar la impunidad y la consiguiente desprotección del bien jurídico. Frente a la inhibición, o a la criminalización de la lesión en términos tan vagos que nada describirían, resulta preferible el recurso a tipos de peligro. $Y$ de peligro abstracto, por cuanto identificar en un bien jurídico de tal amplitud y complejidad un objeto material sometido a riesgo por el comportamiento del sujeto activo sería minimizar la importancia de aquél.

La respuesta legal puede ser distinta cuando se trata de proteger bienes colectivos o sociales funcionalmente necesarios para la defensa de otros (por ejemplo, transparencia en el mercado bursátil para evitar perjuicios a los inversores). Cuando la tutela de un bien jurídico aparece ligada a situaciones determinadas que condicionan su seguridad, el legislador tiene tres opciones: proteger el bien jurídico directamente, desentendiéndose de esa situación instrumental; decidirse por la protección autónoma de la situación instrumental, puesto que así garantizará la del bien "último"; o, finalmente, proteger el bien jurídico siempre que además resulte afectada la situación instrumental. 
En el primer caso el legislador tomará la decisión menos compleja dogmáticamente, pero también menos idónea político-criminalmente. En el segundo los contornos del bien jurídico aparecen desdibujados hasta el punto de hacerlo difícilmente definible y de superponer, confundiéndolos, ilícito penal e ilícito civil o administrativo. La tercera opción es combinación de las anteriores: se protegen bienes jurídicos patrimoniales mediante tipos de resultado-lesión o de peligro, pero condicionando la tipicidad a la afectación negativa a la situación instrumental (seguridad). Esta tercera opción acota el campo delictivo con más rigor que las anteriores -lo que evita la crítica de punitivismo-y, simultáneamente, incorpora una técnica que afronta la tutela tanto de lo individual como de lo colectivo -lo que es, político-criminalmente, más coherente-.$^{35}$

\section{c) Características de los sujetos intervinientes}

Las peculiaridades del marco económico-empresarial en el que se sitúa este tipo de delincuencia, obligan al examen, siquiera sea introductorio, de varias cuestiones.

Un importante ámbito de análisis viene determinado por las características organizativas de la empresa actual, jerarquizada pero, en la misma medida, descentralizada (vide supra 5). Con el riesgo de desplazar la responsabilidad hacia los sectores inferiores del organigrama, ya que solo ellos "ejecutan" directamente la conducta típica.

Ese desplazamiento puede redundar en un notorio menoscabo de la eficacia preventiva de la norma penal, cuyos márgenes de intervención se reducen en un doble sentido: hacia arriba, porque los directivos no realizaron el hecho típico; hacia abajo, porque los ejecutores materiales quedarán frecuentemente al abrigo de la condena, dada la confluencia de factores diversos como son el desconocimiento de las consecuencias de su propio modo de actuación - fruto de la división de trabajo y de la parcelación de la información en la empresa-; la escasa capacidad de resistencia frente a la actitud pro-delictiva del grupo por parte de quien, como regla, está obligado a obedecer dentro de una escala jerarquizada; la eficacia auto-exculpatoria de quien siempre puede alegar que actúa de un modo altruista en interés de la empresa; la alta fungibilidad de los miembros que ocupan las escalas inferiores de la organización, etcétera. ${ }^{36}$

A ello se añade el hecho de que, en derecho penal económico, fuertemente vinculado a la infracción de obligaciones específicas de ciertos sujetos - normal-

35 Terradillos Basoco, Juan Maria. "Peligro abstracto y garantías penales", en Nuevo Foro Penal, Medellín, Colombia, núm. 62, 1999, pp. 85-92.

36 Terradillos Basoco, Juan Maria. "Concepto y método del derecho penal económico", cit., p. 38. 
mente el empresario-, es frecuente el recurso a delitos especiales. En estos casos se provocan lagunas de punibilidad si quien realizó el comportamiento típico no reúne las características requeridas por la ley para el sujeto activo. Tradicionalmente no ha podido responde como autor; ni como partícipe, si nadie lo hace a título de autor, en virtud de la accesoriedad de la participación. Hacer frente a estos supuestos exige o bien incluir cláusulas particulares de extensión de la autoría en cada uno de los delitos en que se estime necesario, o bien introducir una regla general que regule de forma global la actuación en nombre de otro.

Hay que aludir, también, al hecho, por lo demás obvio, de que, en la sociedad actual, los sujetos económicos actúan revistiendo la forma de persona jurídica. Lo que obliga a replantearse la vieja cuestión -formulada por BRICOLA- de si se pueden asumir los costes del principio societas delinquere non potest.

En España, la Ley Orgánica 5/2010, de 22 de junio, ha respondido a la cuestión, introduciendo la posibilidad de exigencia de responsabilidad penal a las personas jurídicas.

En Cuba, el artículo 16.3 del Código Penal cubano, modificado por DecretoLey No. 175 de 17 de junio de 1997, establece que

Las personas jurídicas son penalmente responsables por los delitos previstos en este Código o en leyes especiales, cometidos dentro de la propia esfera de acción de dichas personas jurídicas, cuando sean perpetrados por su representación o por acuerdo de sus asociados, sin perjuicio de la responsabilidad penal individual en que hayan incurrido los autores o cómplices en el hecho punible.

Las sanciones, a imponer de acuerdo con las reglas de los artículos 28.5 y 35.7, son las recogidas en el artículo 28.4.

Sin embargo, en la autorizada opinión de MEjíAs, las previsiones normativas, incluida la instrucción 169 de 15 de enero de 2002, del Tribunal Supremo Popular de Cuba, que estableció las reglas adjetivas de obligatorio cumplimiento por los Tribunales Populares cuando sean juzgadas personas jurídicas, no han rendido todavía todos los frutos esperables. ${ }^{37}$

\section{D) Accesoriedad y remisión normativa}

La intervención punitiva en el complejo y dinámico mundo de la actividad económica exige de la norma penal continuas remisiones a ámbitos normativos extrapenales de muy diverso rango.

37 Mejias Rodriguez, Carlos Alberto. "Estrategias, necesidades y urgencias del derecho penal económico en Cuba", cit. 
La remisión es inevitable, dado que es ilusorio pensar en un Código contemporáneo que pueda cobijar todos los elementos de las diferentes tipologías delictivas en la materia. Por tanto, hay que optar entre dispersar la materia penal en una multiplicidad inacabable de leyes sectoriales, o, como alternativa, mantener la centralidad del Código, con la ventaja de someter toda la normativa penal a principios comunes, lo que obliga al uso de normas penales en blanco.

Esa segunda opción es la del ordenamiento español, ${ }^{38}$ que se encuentra así ante el riesgo de sufrir la indeterminación y carácter meramente sancionador de leyes abiertas a demasiados elementos de integración extrapenal o, incluso a actos administrativos concretos (cláusulas de autorización). Riesgo, pues, de entrar en continua tensión con el principio de legalidad.

Sin embargo, la remisión normativa, inevitable en la materia, no tiene por qué comportar mengua de garantías.

La doctrina española mayoritaria y la jurisprudencia, sobre todo la emanada del Tribunal Constitucional, estiman que el recurso a los reglamentos es compatible con el principio de legalidad si el legislador toma la decisión incriminadora básica -aunque ceda a la Administración el concretar esa decisión-; si, además, la remisión en el precepto penal a la norma de complemento es expresa; y si, finalmente, resulta justificada en atención al bien jurídico protegido.

En definitiva, se trata de garantizar el carácter complementario del reglamento, como enunciación técnica o de detalle, reservándose la norma penal la definición del núcleo esencial de lo prohibido. ${ }^{39}$ Dado ese primer paso, la norma subordinada no puede ampliar, sino restringir, el campo de lo típico.

La remisión normativa plantea también problemas específicos en el ámbito aplicativo. Son, en primer lugar, los relacionados con el principio non bis in idem, a los que se debe responder, en términos semejantes a como lo hace en España la jurisprudencia constitucional, partiendo de que no cabe doble sanción con el mismo presupuesto. Y de que, sensu contrario, no puede apreciarse identidad de presupuesto, y por tanto es admisible la pluralidad de sanciones 0 , al menos, de procedimientos, allí donde son distintos los hechos examinados, el fundamento de la sanción o los sujetos sobre los que recae ésta.

Con todo, la aparente claridad de estas reglas queda en entredicho cuanto la práctica determina que, antes de la sentencia en vía jurisdiccional penal, haya alcanzado firmeza o, incluso, se haya ejecutado, la sanción administrativa por

38 Terradillos Basoco, Juan Maria. "Per un modello pancodicistico: I'esperienza spagnola", en Doninı, Massimo (ed.). Modelli ed esperienze di riforma del Diritto penal complementare, Giuffrè, Milán, 2003, passim.

39 Lamarca Pérez, Carmen. "Legalidad y reserva de ley en la Constitución española", en Revista Española de Derecho Constitucional, núm. 20, 1987, p. 113. 
el mismo hecho. La sentencia del Tribunal Constitucional español 177/1999, se decantó por la nulidad de la segunda sanción, por imponerlo así el principio non bis in idem, cuya vigencia no puede quedar supeditada a la preferencia cronológica del procedimiento administrativo, preferencia patológica no imputable al sujeto sancionado. En cambio el mismo Tribunal, en sentencia 2/2003, impuso un cambio radical de rumbo, luego seguido por la sentencia 334/2005 y por el Tribunal Supremo en sentencia de 25 de mayo de 2004, al proclamar que no queda conculcado tal principio por la sentencia penal condenatoria que descuenta de la pena la sanción administrativa, "al no haberse producido una duplicación de la sanción constitutiva del exceso punitivo materialmente proscrito por el art. 25.1 CE”. Parece, sin embargo, evidente, que es al legislador a quien compete positivizar el razonable criterio de la compensación..$^{40}$

La remisión normativa puede dar lugar también a situaciones controvertidas, cuando esa remisión lo es a infracciones administrativas integradas en el tipo penal, de suerte que la apreciación de aquellas -realizada de ordinario por la autoridad administrativa- condiciona la aplicación del precepto penal. ${ }^{41}$ Aunque esta "prejudicialidad" administrativa pueda, de hecho, sustraer del juez penal la facultad de apreciar o no la concurrencia de delito, no es esa la consecuencia deseable ni tampoco la inevitable. Para los tribunales españoles, por ejemplo, resulta indiscutida la autonomía de que goza el orden jurisdiccional tanto en la apreciación de los hechos como en la valoración de la gravedad de las infracciones. Una y otra labor son independientes de las que, previamente, hayan podido realizar las autoridades gubernativas.

La autonomía e independencia judicial se extienden, pues, sobre todos los elementos del tipo delictivo, incluso los que se encuentran extra lege poenale. Lo que viene a traducirse en que la intervención de la autoridad administrativa no debe tener, en el proceso penal, otra consideración que la de denuncia o de un elemento probatorio más.

\section{E) Directrices criminalizadoras}

Tradicionalmente se han venido atribuyendo al derecho penal económico funciones diversas, pero todas ellas giran en torno a la tutela de bienes jurídicos surgidos en el marco de la actividad económico-empresarial.

El Estado social, en efecto, vincula el ordenamiento formal a sus presupuestos materiales y le niega al mercado la capacidad de autorregulación: "El Estado

\footnotetext{
40 Terradillos Basoco, Juan María. "Concepto y método del derecho penal económico", cit., p. 54.

${ }^{41}$ Mejias Rodriguez, Carlos Alberto. "Ámbito procesal del derecho penal económico en Cuba", cit., p. 123.
} 
social regula de forma positiva e interviene activamente sobre la realidad social para construir un orden igualitario". ${ }^{42}$

La construcción del orden igualitario, en su dimensión político-criminal, comporta, pues, el protagonismo del Estado, que ha de intervenir decididamente, no ya para culminar esa construcción a través del derecho penal -que es instrumento inidóneo-, pero sí para imprimir a los procesos de criminalización y descriminalización una orientación y unos contenidos que no entren en colisión con el objetivo prioritario. El Estado social no puede, así, inhibirse delegando sus responsabilidades en el mercado; ha de asumirlas tutelando, incluso penalmente, los derechos fundamentales y los bienes jurídicos básicos que nacen y se desenvuelven en el propio mercado.

Ese es el origen del derecho penal económico. De modo que, junto a la inevitable descriminalización inherente a todo programa de derecho penal mínimo, que es el único democrático, se deben abrir procesos legislativos de criminalización de los nuevos delitos económicos o de las nuevas formas en que se manifiestan.

En España el catálogo es amplio: insolvencias punibles, alteración de precios en concursos y subastas públicas, delitos relativos a la propiedad industrial, a la intelectual, al mercado y a los consumidores, delitos societarios, y blanqueo de capitales y receptación. A estos delitos, cobijados -aunque no sin dudas- bajo la rúbrica legal de delitos contra el orden socioeconómico en el título xill del libro $॥$ del cP, se añaden otros que, tanto por sus características criminológicas y su morfología como por las técnicas seguidas por el legislador al construir los concretos preceptos, presentan una evidente proximidad con los mencionados. Se trata de los delitos contra la Hacienda Pública y contra la Seguridad Social, de los delitos contra los derechos de los trabajadores y de los delitos relativos a la ordenación del territorio y el urbanismo, la protección del patrimonio histórico y del medio ambiente.

En Cuba, la referencia es el título v del cPc: "Delitos contra la economía nacional”, pero también en otros lugares del Código, tras las modificaciones operadas en el mismo por los decretos leyes 150, de 6 de junio de 1994, y 175, de 17 de junio de 1997, se encuentran figuras delictivas paralelas a las que, en sistemas penales de países de economía de mercado, son calificadas como delitos económicos o socio-económicos: evasión fiscal, delitos contra los derechos laborales, actos en perjuicio de la actividad económica o la contratación, delitos contra

\footnotetext{
42 Baylos Grau, Antonıo. "A importância da realização do Estado social". Disponible en http://www.dmtemdebate.com. br/abre_noticia_colunista.php?id=34 [Citado: 1.Enero.2015].
} 
el patrimonio cultural, insolvencias punibles, lavado de dinero, enriquecimiento ilícito, etcétera. ${ }^{43}$

Por su parte, la Circular No. 240 de 2008, del presidente del Tribunal Supremo Popular, sin llegar a definir los delitos económicos o los de corrupción, sí señala las tipicidades delictivas más frecuentes que pudieran estar relacionados con esas categorías. Son: "revelación de pruebas para la evaluación docente (Artículo 132), abuso de autoridad (Artículo 133), prevaricación (Artículo 136), ejecución indebida de sanciones o medidas de seguridad (Artículo 141), enriquecimiento ilícito (Artículo 150), tráfico de influencias (Artículo 151), cohecho (Artículo 152), exacción ilegal y negociaciones ilícitas (Artículo 153), encubrimiento (Artículo 160), incumplimiento del deber de denunciar (Artículo 161), sustracción y daño de documentos $u$ otros objetos en custodia oficial y violación de sellos oficiales (Artículo 168), infracción de las normas de protección de documentos clasificados (Artículo 169), todos los delitos contra la economía nacional y contra la fe pública recogidos en los títulos $\vee$ y vll, estafa (Artículo 334), apropiación indebida (Artículo 335), malversación (Artículo 336), evasión fiscal (Artículo 343) y lavado de dinero (Artículo 346)", todos ellos del Código Penal cubano. ${ }^{44}$

La Ley 118 , a su vez, viene a recordar la vigencia de las leyes cubanas en los ámbitos de actividad de las inversiones extranjeras: legislación laboral y de seguridad social (artículo 27), obligaciones tributarias (artículo 34), sometimiento a las normas de control financiero y de comercio exterior (artículos 52 y 53), conservación del medio ambiente y uso racional de los recursos naturales (artículo 54), etcétera.

Se trata de un mero recordatorio, pero resulta obvio que la apertura a las compañías extranjeras determinará cambios en el mundo económico, que invitan a revisar críticamente el panorama normativo, para mejor adecuarlo a las nuevas necesidades $y$, sobre todo, a las nuevas situaciones conflictuales.

Quizá, en esa labor de revisión de las conductas criminalizables, pudieran servir de ayuda los más reconocidos intentos de cubrir los mismos objetivos en el marco de la Unión Europea.

El primero de ellos, el Corpus Iuris (1998), responde a un encargo del Parlamento Europeo y de la Comisión Europea a un grupo de especialistas. Se pretendía obtener un primer proyecto de criminalización no de delitos socioeconómicos, sino tan solo de delitos contra los intereses financieros de la Unión, de ahí que el catálogo no fuera muy extenso: fraude al presupuesto comunitario, fraude en concursos y subastas públicos, blanqueo de activos y receptación.

\footnotetext{
${ }^{43}$ Mejias Rodriguez, Carlos Alberto. "Ámbito procesal del derecho penal económico en Cuba", cit., pp. 117 y 118.

44 Ibidem, p. 131.
} 
Pero se añaden también delitos cometidos por funcionarios públicos susceptibles de ocasionar un perjuicio a los intereses financieros europeos, lo que supone ampliar considerablemente el catálogo: corrupción, abuso del cargo en la concesión de ayudas y subvenciones, malversación de caudales públicos, revelación de secretos oficiales y asociación ilícita. Además, y quizá esta sea la aportación más importante del Corpus Iuris, se incorporan preceptos propios de una parte general, relativos al tipo subjetivo de la infracción, al error, a la autoría y participación, y a la determinación de la pena. ${ }^{45}$

Posteriormente, en 2002, un grupo de estudiosos universitarios lanzó la propuesta denominada "Eurodelitos". ${ }^{46}$ Se trata de un boceto de tipificación de la delincuencia económica "latamente concebida", estructurado en torno a siete títulos: ı. Protección de los trabajadores y del mercado de trabajo; ı. Protección del consumidor y de la competencia; il. Protección del medio ambiente; iv. Insolvencias punibles y delitos societarios; v. Protección del crédito, la bolsa y el ahorro; vi. Protección de la marca comunitaria; y vı. Protección de las medidas sancionadoras adoptadas por la Comunidad Europea o por otros organismos internacionales. ${ }^{47}$

\section{F) Cuestiones procesales}

Los retos planteados a la política criminal por la gran delincuencia económica trascienden el horizonte dogmático-sustantivo para situarse, también, en el plano procesal. Son problemas probatorios los que obstaculizan la correcta identificación de los centros decisores y ejecutores, la delimitación de las respectivas responsabilidades, o la efectiva exigencia de responsabilidad penal allí donde ha logrado ser determinada. Lo que es muy de lamentar en la lucha contra la criminalidad de cuello blanco, protagonizada por "delincuentes de cálculo": la alta probabilidad de evitar la condena penal, y, si es que llega a pronunciarse, de eludir la ejecución de la pena carcelaria o pecuniaria, o de burlar el decomiso de los bienes, dejan en nada la presunta capacidad desincentivadora de la conminación penal..$^{48}$

\footnotetext{
45 Martinez Buján-Pérez, Carlos. Derecho penal económico y de la empresa. Parte general I, 4a. ed., Tirant lo Blanch, Valencia, 2014, p. 107.

46 Tiedemann, Klaus (dir.). Eurodelitos. El derecho penal económico de la Unión Europea, Universidad de Castilla-La Mancha, Cuenca, 2003, passim.

47 Martinez Buján-Pérez, Carlos. Derecho penal económico y de la empresa. Parte general I, cit., pp. 107 y 108.

48 Del Moral Garcia, Antonio. "La lucha contra la corrupción, una tarea juridica, ética y educativa. Propuestas y perspectivas de la sociedad en la lucha contra la corrupción", cit.
} 
Frente a ello se impone la superación de un proceso penal nacido para responder a una realidad primitiva y simple, ${ }^{49}$ implementando un procedimiento ágil y no trabado por plazos prescriptivos perentorios, ${ }^{50}$ capaz de saltar fronteras -a través de mecanismos como la justicia universal o a través de la cooperación internacional-, ${ }^{51}$ atento a las peculiaridades organizativas de las personas jurídicas, adaptado a los contenidos del derecho penal sustantivo, idóneo, en definitiva, para asegurar el juicio justo y legal, pero también para acabar con la impunidad de las estrategias mercantiles basadas en la minimización de costes y en la elusión de responsabilidades.

Todo ello pasa, naturalmente, por la incorporación a los tribunales penales de salas especializadas con jueces expertos en el conocimiento de la economía y de sus protagonistas, de la normativa mercantil y tributaria, así como de la laboral o de la internacional, amén de la capacitación, como conditio sine qua non, en materia penal. $Y$ allí donde no llegue el juez, que tendrá como todos los humanos capacidad limitada, deberá ser asistido por profesionales, incluso ajenos al derecho que, incorporados a los juzgados, puedan auxiliarle eficazmente. De otro modo, la balanza del proceso penal se vencerá hacia el lado de los poderosos equipos de abogados y asesores que asisten al gran delincuente de cuello blanco.

Todo ello, no obstante, serviría de muy poco si no se cuenta con una policía científica experimentada que trabaje codo con codo con un Ministerio Fiscal igualmente especializado. ${ }^{52}$

Quizá solo a través de la potenciación de los recursos humanos de la Administración de Justicia pueda superarse una lacra histórica de nuestros sistemas procesales, que es, además, prenda segura de ineficacia preventiva: la irrecuperabilidad de los ilegítimos beneficios del delito.

En ningún caso -denuncia con ironía GALEANO-, nunca nadie en la historia de América latina ha sido obligado a devolver el dinero que robó: ni los presidentes derribados, ni los muchos ministros renunciados por comprobada corrupción, ni los directores

\footnotetext{
${ }^{49}$ El propio presidente del Tribunal Supremo español ha identificado como una insalvable traba en la lucha contra la corrupción, el hecho de que la legislación procesal penal española "está pensada para el robagallinas, no para el gran defraudador". Disponible en: http://www.europapress.es/nacional/noticia-lesmes-dice-ley-pensada-robagallinas-nogran-defraudador-reclama-reformas-20141021210108.html [Consulta: 31.Enero.2015].

50 Grupo de Estudios de Politica Criminal. Una alternativa a algunas previsiones penales utilitarias. Indulto, prescripción, dilaciones indebidas y conformidad procesal, Tirant lo Blanch, Valencia, 2014. Disponible en: http://www.gepc.es/ web/sites/default/files/ficheros/libro15_0.pdf [Consulta: 31.Enero.2015].

51 Mejias Rodriguez, Carlos Alberto. Delitos asociados a la contratación económica, Ediciones onbc, La Habana, 2013, p. 18.

52 Del Moral Garcia, Antonio. "La lucha contra la corrupción, una tarea jurídica, ética y educativa. Propuestas y perspectivas de la sociedad en la lucha contra la corrupción", cit.
} 
de servicios públicos, ni los legisladores, ni los funcionarios que reciben dinero por debajo de la mesa. Nunca nadie ha devuelto nada. No digo que no hayan tenido la intención: es que a nadie se le ocurrió la idea. ${ }^{53}$

\section{Epílogo}

Los costes de la delincuencia económica, que superan en mucho los tradicionales efectos del delito, son ingentes. El fraude fiscal supera, en países como Estados Unidos o Gran Bretaña, el 15\% del total de los impuestos, a lo que se añaden la alteración de las políticas de gasto que provoca, y la consiguiente redistribución, al alza, de la carga impositiva que corresponde a los ciudadanos cumplidores de sus obligaciones tributarias. ${ }^{54}$ En España, por poner solo un ejemplo, la economía sumergida alcanza el 24,6\% del PIB, más de 250.000 millones de euros. ${ }^{55}$

Por no aludir a los no cuantificables, por su magnitud, costes de la crisis financiera y económica que asola a las economías europeas desde 2008, y en cuyo origen está, como fuente reconocida, una desregulación normativa y, más en concreto, una inhibición penal que se ha constituido en cómplice y encubridora de los episodios de delincuencia económica más importantes de la historia. ${ }^{56}$

Pero la gran delincuencia económica genera otros costes; no económicos, aunque no por ello menos relevantes. Se trata de los costes políticos y sociales de las estrategias político-criminales dirigidas a afrontarla. Más en concreto, se corre el riesgo de que una política criminal expansionista lleve a tipificaciones o sanciones que entren en intolerable contradicción con principios esenciales al sistema penal democrático. ${ }^{57}$

Manifestaciones paradigmáticas de expansionismo, ya han sido analizadas: es el caso, por ejemplo de la criminalización de delitos meramente formales o de delitos de peligro presunto. Pero junto a esta realidad expansiva -selectiva y limitada en el caso de la delincuencia económica, aunque ha terminado por infectar todo el sistema penal- coexiste la inhibición punitiva que la lex mercatoria impone en las actividades económicas.

${ }^{53}$ Galeano, Eduardo. Patas arriba. La escuela del mundo al revés, Catálogos, Buenos Aires, 2006, p. 153.

${ }^{54}$ Vera Priego, Juan Manuel. Nuevos mecanismos de fraude fiscal. Algunas propuestas para un modelo de investigación, Fundación Alternativas, Madrid, 2008, pp. 7-10.

${ }_{55}$ SARDÁ, JoRDI (dir.). La economía sumergida pasa factura. El avance del fraude en España durante la crisis, 2014. Disponible en: http://www.nuevatribuna.es/media/nuevatribuna/files/2014/03/12/323fc63650907548f7491c007d9 99603.pdf [Consulta: 31.Enero.2015].

${ }^{56}$ Terradillos Basoco, Juan Maria. "Política criminal de materia socioeconómica: hacia el derecho penal de la exclusión", en Medina Cuenca, Arnel (coord.). El derecho penal de los inicios del siglo xxl en la encrucijada entre las garantías penales y el expansionismo irracional. Libro homenaje al Dr. Ramón de la Cruz Ochoa, presidente de honor de la Sociedad Cubana de Ciencias Penales, unIunIs, La Habana, 2014, edición digital, p. 97.

57 Hassemer, Winfried y Muñoz Conde, Francisco. La responsabilidad por el producto en derecho penal, cit., pp. 25-29. 
La técnica más socorrida, y más sofisticada, para eludir las responsabilidades propias del Estado social de derecho en materia de lucha contra la delincuencia económica, es la reducción del sistema penal al despliegue de su función simbólica. Fundamentalmente en su forma de enmascaramiento de la realidad, con la creación de apariencia de resolución de conflictos que permanecen intocados, ${ }^{58}$ haciendo creer en el imposible cumplimiento de objetivos inaccesibles porque, en el fondo, no son los realmente perseguidos. En estos casos lo simbólico ha cedido al enmascaramiento ideológico, ${ }^{59}$ y el sistema opta por la inhibición; negándola en sus proclamas, pero aceptándola en sus consecuencias materiales. ${ }^{60}$ En suma, desprotección programada, en la medida en que, a una tipificación inadecuada suele acompañar la ausencia de otras políticas sociales o de prevención más costosas. ${ }^{61}$

El precio a pagar por la opción en favor de la denominada función simbólica es la pérdida de eficacia, frente a conductas de enorme potencialidad lesiva para intereses generales, pero que pueden resultar tremendamente lucrativas, en un mercado que, perdida la referencia a valores, sólo reconoce, como objetivo $-\mathrm{y}$ principio-supremo, la obtención de lucro.

Para superar el riesgo de reducir el derecho penal económico a mera función simbólica y dotarle de eficacia preventiva, que es lo que se le debe exigir, es preciso inicialmente el máximo aprovechamiento de las posibilidades preventivas propias de los mecanismos resarcitorios, de los medios de autotutela de potenciales víctimas, de los programas públicos de incentivación y promoción, del control y de las sanciones administrativas, etcétera.

Son el ineludible marco condicionante y antecedente lógico de la política criminal en sentido estricto. Sólo con ese punto de partida el derecho penal económico puede aspirar a cierta eficacia preventiva sin necesidad de subvertir los principios de todo el sistema penal.

Sin necesidad de recurrir a lo excepcional es factible racionalizar la prevención, prestando, de lege ferenda, una mayor atención a los bienes jurídicos más gravemente puestos en peligro en el marco de la actividad económica. Lo que

58 "Una demostración de fuerza huera por parte del Estado": Diaz Pita, Maria del Mar y Faraldo Cabana, Patricia. "La utilización simbólica del derecho penal en las reformas del Código Penal de 1995", en Revista de Derecho y Proceso penal, núm. 7, 2002, pp. 119-124.

${ }^{59}$ En este sentido, Diez RipolıÉs, José Luis. "El derecho penal simbólico y los efectos de la pena", en varios Autores. Modernas tendencias del derecho penal y de la criminologia, unED, Madrid, 2001, p. 122.

${ }^{60}$ Gráficamente se ha dicho que "con estas normas el legislador deslumbra al ciudadano, lo entretiene y poco más. No es que sean efectos ilegítimos, es que no producen ninguno [...] Esto es lo criticable, y lo es por constituir un engaño": Díaz Pita, María del Mar y Faraldo Cabana, Patricia. "La utilización simbólica del derecho penal en las reformas del Código Penal de 1995", cit., p. 127.

${ }^{61}$ Silva Sánchez, Jesús Maria. La expansión del derecho penal. Aspectos de la política criminal en las sociedades postindustriales, Civitas, Barcelona, 1999, p. 123. 
implica la obligación de meditar y decidir sobre las técnicas -incluyendo las jurídico-penales- más idóneas para combatir los delitos protagonizados por la empresa como sujeto económico. No se trata, pues, de que el legislador articule ambiciosos proyectos de nuevas criminalizaciones, tomando el bien jurídico no como límite sino como trampolín impulsor de la expansión penal; por el contrario, se trata de que, con escrupuloso respeto al principio de lesividad, considere, simplemente, que la actividad empresarial reúne características específicas que requieren respuestas también específicas.

Y, de lege lata, es necesario que los operadores jurídicos actúen, en sus respectivos ámbitos, con la misma consciencia de las peculiaridades propias del mundo empresarial. De otro modo, su labor terminará por traicionar el sentido de las normas que tienen el deber de aplicar. ${ }^{62}$

Si la situación es esta, el reto no puede ser una nueva dogmática legitimadora de la expansión. Aunque esta sea retórica, es siempre bacteria que termina infectando todo su entorno. El reto está en valorar en su exacta importancia los bienes jurídicos afectados por la delincuencia económica y en avanzar en el conocimiento de los ataques que se les infligen, para, lejos de la inhibición cómplice o del punitivismo exacerbado -ambos inconstitucionales-, diseñar las estrategias político-criminales con el caudal dogmático heredado, pero ahora dirigido a hacer frente a las nuevas realidades.

62 Terradillos Basoco, Juan Maria. "El «derecho penal del trabajo». ¿Una opción pertinente?", en Derecho Laboral. Revista de Doctrina, Jurisprudencia e Informaciones Sociales, Montevideo, núm. XLIX, 2006, pp. 498 y 499. 